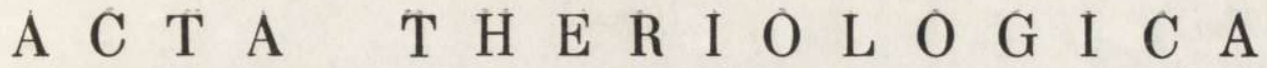 \\ VOL. XVI, 3: $61-71$. \\ BIAEOWIEŻA \\ April, 1971
}

\author{
Zenona NOW A K
}

\section{The Eifect of Removing a Dominant on the Social Organization of Laboratory Mice Populations}

[With 3 Tables \& 5 Figs]

\begin{abstract}
Observations were made to see how the removal of a dominant affects the social organization in populations of laboratory mice, in 4 series covering 66 populations. Aggresive contacts between individuals in the population were recorded. After each week of observations the dominant, that is, the male which engage in and won the largest number of fights was removed from the population. Intensivity of fights exhibits a tendency to decrease from the time of forming population. Removal from the population of the first and second dominant causes increase in intensivity of biting, which shows that the hierarchy has been disturbed. After the dominant is removed social organization reforms, i.e. a new dominant is created. There is a tendency for the most beaten individual to occupy the dominant's place. After two populations are combined there is a tendency for one population to dominate over the other.
\end{abstract}

\section{INTRODUCTION}

The social organization, that is, subordination of some individuals to others, in mice populations reared under laboratory conditions has been described in detail by Uhrich (1938). Non-competitive fights between. males, on the basis of which it is possible to assess the social organization and its effect on the fate of individuals and the whole population, have been observed by many researchers, including $\mathrm{Fr}$ eder i cson \& Scott (1951; after Crowcroft, 1962), Brown (1953), Southwick (1955), Petrusewicz \& Wilska (1959), Petrusewicz \& Andrychowska (1960), Petrusewicz (1966). It would seem that individuals standing highest in the social hierarchy play a particularly important role in the population, as all the individuals in the population are subordinated to them.

The purpose of this study was to establish the following (1) whether removal of the dominant from the population causes disturbances in the 
latter's social organization, (2) whether the place of the removed dominant is occupied by a successor, or whether it remains unoccupied, (3) whether intensivity of fights in the population decreases as successive dominants are removed from it.

\section{METHODS}

Observations were made of populations of laboratory mice placed in cages measuring $160 \times 40 \times 15 \mathrm{~cm}$. The top of the cage was made of netting through which the animals could be observed. Food (LSM compressed pellets, made by the firm of Bacutil) and drinking water were given ad libitum.

Mice 3-5 months old were taken for the experiments, the males in the population being of uniform age. The age of the males was chosen in accordance with the observations made by Uhrich (1938), which show that males manifest maximum activity at this age. The males were marked individually by painting the coat before beginning the experiment.

Aggressive contacts between individuals in the population were observed, and the following recorded: (1) which mouse bits which, in this way distinguishing the dominant, (2) number of bites in 5-minute intervals of time, (3) mortality among the individuals.

Uhrich (1938) found that males are more aggressive in fights than females and consequently play a more important part in them, but B rown (1953) considers that females should not be overlooked in this respect, as they become more aggressive for a short time either before or after the birth of their young, and consequently increase the number of fights. In this connection a record was kept of the fights of both males and females in units of time and also of which individuals fought with which, the numbers of the antagonists being recorded in the case of males. Dominants were defined in each population on the basis of maximum number of fights won. Each population was observed 3 times a week for 4 hours at a time, in the evening.

Experiments consisting in removing the observed dominants from the population were carried out in 4 series on a total number of 66 populations of laboratory mice.

Series I: 16 populations consisting of 5 males and 5 females. After a week's observation the first dominant was removed from each population, then the successive second and third dominant was removed every week. After 4 weeks the dominant first removed was replaced in the population and fights observed for a further week (thus making a total of 5 weeks).

Series II: composed of 20 populations, and observations made in the same way as in series I, except that they lasted 4 weeks, i.e. the first dominants were not introduced into the populations.

Series III: 16 populations composed of 3 males and 3 females were placed in cages divided into two parts. Each »original " population was placed in one half of the cage. After a week's observations and determination of the dominant in each population the partition dividing the cage was removed. For the week after combined the population observations were made to see which individual became dominant in the combined population, after which it was removed. The continuation of series III was identical with series I and consisted in weekly removal from the population of successive dominants. 
Series IV: carried out in order to supplement data obtained in series III. Observations were made of 22 populations in a similar way to series III, except that records were kept only of which males fought each other, without recording the number of fights.

\section{VARIATIONS IN INTENSIVITY OF BITING}

Analysis of intensivity of biting was based on data series I, II and III, calculating the average number of fights in a population per 5 minutes during the experiment period, as the dominants were removed. In all the series the number of fights in the population decrease with time (Fig. 1). The number does not increase again until the final week, when

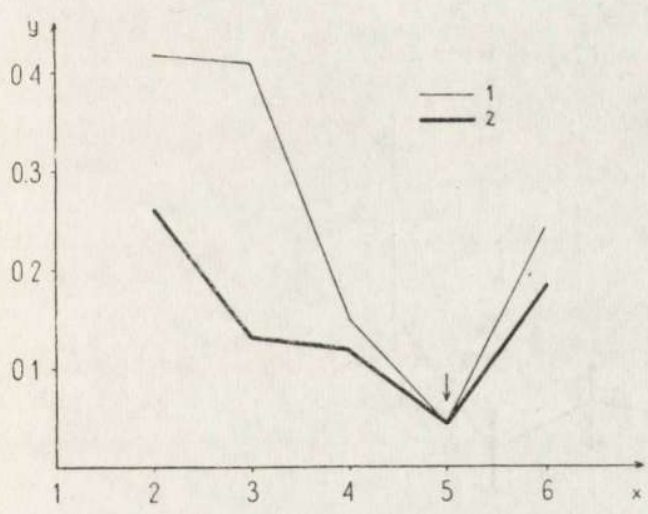

Fig. 1

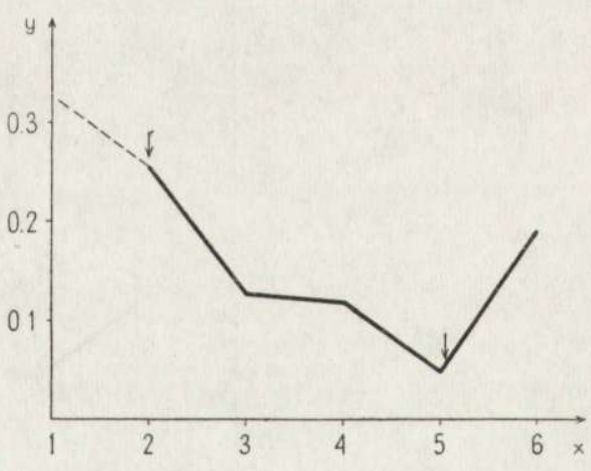

Fig. 2

Fig. 1. Variations in intensiveness of fights during experiment. $x$ - successive weeks, $y$ - average number of fights during 5 -minute periods per population. Arrow indicates introduction of first dominant. 1 - data for series I + II, 2 - data for series III.

Fig. 2. Variations in intensiveness of fights when populations are united (series III). $x$ - successive weeks, $y$ - average number of fights during 5-minute periods per population. Arrows indicate: 1. uniting of two populations, 2. introduction of first dominant. Dotted line - data for "original " populations.

the first dominant is replaced in the population (Fig. 1). In series III intensivity of fights is lower than in series I and II, and in addition the average number of fights per 5 minutes, after the two populations have been combined, is lower than when the populations were first formed (Fig. 2). The large number of fights after forming the populations can be explained by the aggressive behaviour of mice during the formation of the social organization. 
A decrease is also observed in the number of fights per male in successive weeks of the experiment (Fig. 3). This shows that the general decrease in the number of fights is not due to the smaller number of males, but to the general tendency to decrease in the number of fights in the population with the passage of time. Calculation was made of the standard deviations for the number of fights per male for 5 minutes during the successive weeks of the experiment. They show that in the 2nd, 3rd and 6th week there is a difference in the course of the two curves (Fig. 3), i.e. standard deviations have no common values. In weeks 4 and 5 differences between curves are not significant, as the values of standard deviations almost coincide. It would seem that this may be due

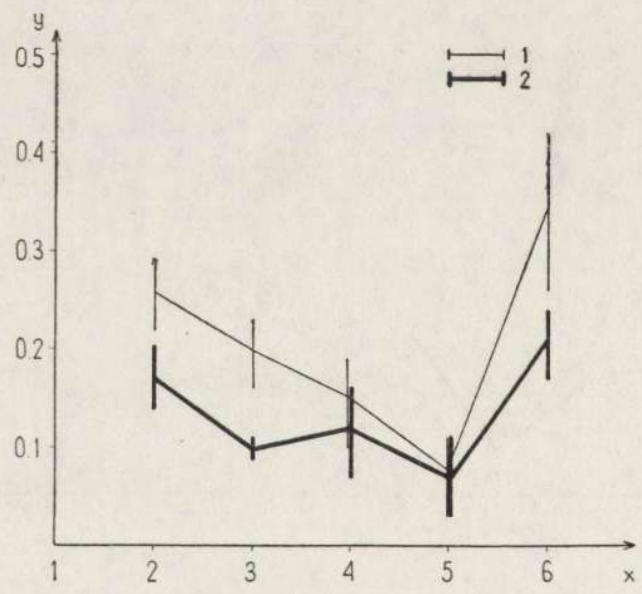

Fig. 3. Variations in intensiveness of fights per male.

$x$ - successive weeks, $y-$ average number of fights during 5-minute periods per male. Vertical lines indicate standard deviations. 1 - data for series I + II, 2 data for series III.

to the different initial number of males in the population and the consequently different social organization in these populations.

In order to check whether removal of the dominant causes a change in the number of fights, comparison was made of the intensity of fights during consecutive observations after each removal of a dominant. It was found that irrespective of the general tendency to a decrease in intensity of fights in a population in time, after the first two dominants had been removed the number of fights at first increased, later to decrease during the week to a level below that observed before removal of the dominants. After removal of the third successive dominant the number of fights in the population was by then very small and no increase was observed in them (Fig. 4). 


\section{SOCIAL ORGANIZATION}

A check was made to see whether after removal of the dominant it is possible to observe renewed establishment of social organization in all cases. Both after setting up a population and after removal of two dominants social organization was always observed (Table 1). After removal of the subsequent dominant the number of populations in which social organization was observed decreased and in the penultimate week of the experiments occurred in only 40 populations out of 62 . The decrease in the number of cases observed of occurrence of social organization may be due not only to absence of this organization. As intensity of fights decreases during the time the population lasts (Fig. 1) a 12-hour observation of contacts between individuals during a week may be insufficient

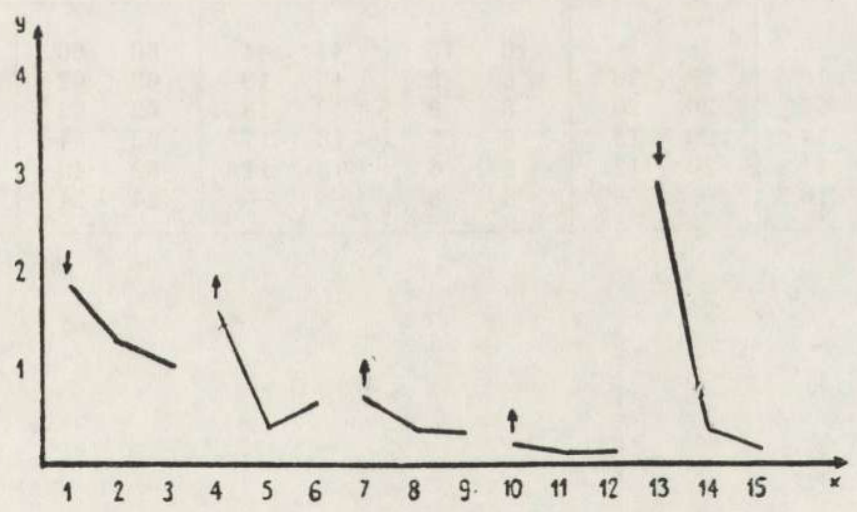

Fig. 4. Variations in intensiveness of fights during the sway of one dominant. $x$ - successive observations, $y$ - average number of fights during 5 -minute periods per population. Arrows pointing downwards indicate. 1. formation of population, 2. introduction of first dominant. Arrows pointing upwards indicate removal of successive dominants.

to reveal infrequent fights, which form the basis for conclusions as to social organization.

After replacing the first dominant in the population the hierarchy was observed again in all the populations (Table 1). After being replaced in the population the first dominant returns to its former place in only $37 \%$ of the cases, and in $63 \%$ fails to occupy its former position. It would therefore seem that the period of 3 weeks is generally sufficient for the dominant to be forgotten by the population and to be treated by it as a newcomer.

In turn analysis was made of the period required for the successor to occupy the place left by removal of the dominant. For this purpose cal- 
culation was made after each removal of a dominant of the number of populations in which a new dominant was constituted on the 1st, 3rd and 5th day (as observations were made on these days). If no dominant made its appearance after this period the time taken for it to emerge was accepted as 5 days, although in fact this period was exceeded. The

Table 1

Occurrence of domination organization in populations during the experiments. 1 - Total number of populations; 2 - Populations with established organization.

\begin{tabular}{|c|c|c|c|c|c|c|c|c|c|c|c|}
\hline \multirow{2}{*}{ Week } & \multicolumn{2}{|c|}{ Series I } & \multicolumn{2}{|c|}{ Series II } & \multirow{2}{*}{\multicolumn{2}{|c|}{$\begin{array}{cc}\text { Series } & \text { III } \\
1 & 2\end{array}$}} & \multirow{2}{*}{\multicolumn{2}{|c|}{$\begin{array}{cc}\text { Series } & \text { IV } \\
1 & 2\end{array}$}} & \multicolumn{2}{|c|}{ Total } & \multirow{2}{*}{$\begin{array}{l}\text { Percentage } \\
\text { of cases in } \\
\text { which orga- } \\
\text { nization was } \\
\text { observed }\end{array}$} \\
\hline & & 2 & & 2 & & & & & & 2 & \\
\hline 1. & - & - & - & - & 16 & 16 & 44 & 44 & 60 & 60 & 100 \\
\hline 2. & 16 & 16 & 20 & 20 & 8 & 8 & 18 & 18 & 62 & 62 & 100 \\
\hline 3. & 16 & 16 & 20 & 20 & 8 & 8 & 18 & 18 & 62 & 62 & 100 \\
\hline 4. & 16 & 14 & 20 & 15 & 8 & 8 & 18 & 17 & 62 & 54 & 87 \\
\hline 5. & 16 & 11 & 20 & 12 & 8 & 6 & 18 & 11 & 62 & 40 & 64 \\
\hline 6. & 16 & 16 & - & - & 8 & 8 & - & - & 24 & 24 & 100 \\
\hline
\end{tabular}

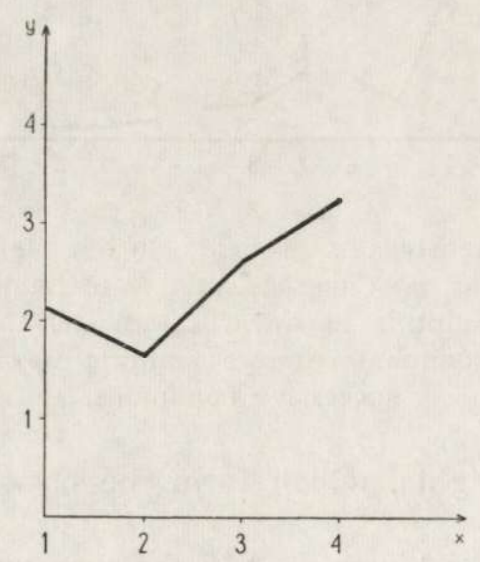

Fig. 5. Variations in rapidity with which successive dominants arise.

$x$ - successive dominants, $y$ - mean time taken for a dominant to arise, in days.

average time required to occupy the position of dominant was calculated (Fig. 5). These values vary from 1.7 to 3.3 days. During the 3 rd and 4 th week of observations the factual time taken to constitute a dominant probably exceeds the values 2.6 and 3.3 days, since in many populations (19) it proved impossible to observe social organization. 
By direct observations individuals more or less beaten by the dominant were found in a population. After removing the dominant a check was made to see which individual had taken its place. Material from series I, II and III was taken into consideration (Table 2). The data obtained show that out of a total of 132 cases, in 61 the dominant's place is taken by the most beaten male, in 43 cases by another male and in 18 cases no social organization could be described. A check was made for each series to ascertain whether this is a random or regular phenomenon. When the population consists of more than two individuals the

Table 2

Occupation of dominant's place by most beaten male.

\begin{tabular}{|c|c|c|c|c|c|c|c|}
\hline \multirow[b]{2}{*}{ Series } & \multirow[b]{2}{*}{$\begin{array}{l}\text { No. of } \\
\text { populat- } \\
\text { ions }\end{array}$} & \multirow[b]{2}{*}{$\begin{array}{l}\text { No. of } \\
\text { removals }\end{array}$} & \multicolumn{3}{|c|}{ Number of cases of: } & \multicolumn{2}{|c|}{ Occupation of place } \\
\hline & & & $\begin{array}{l}\text { Change } \\
\text { of dom- } \\
\text { inant }\end{array}$ & $\begin{array}{c}\text { Domina- } \\
\text { tion of } \\
\text { beaten } \\
\text { male }\end{array}$ & $\begin{array}{l}\text { Absence } \\
\text { of orga- } \\
\text { nization }\end{array}$ & Theoret. & Emp. \\
\hline I & 16 & 3 & 48 & 21 & 6 & 0.75 & 0.85 \\
\hline II & 20 & 3 & 60 & 28 & 11 & 0.75 & 0.94 \\
\hline III & 8 & 3 & 24 & 12 & 1 & 0.60 & 0.75 \\
\hline Total & 44 & 3 & 132 & 61 & 18 & & \\
\hline
\end{tabular}

Table 3

Occupation of dominant's place by individuals of the same population.

\begin{tabular}{|c|c|c|c|}
\hline \multirow{3}{*}{ Series } & $\begin{array}{c}\text { Number of populations } \\
\text { after uniting in twos }\end{array}$ & \multicolumn{2}{|c|}{$\begin{array}{c}\text { Number of populations with } \\
\text { successive dominants }\end{array}$} \\
\cline { 3 - 4 } & & Twice & Three times \\
\hline I & 8 & 7 & 5 \\
II & 18 & 11 & 6 \\
Total & 26 & 18 & 11 \\
\hline
\end{tabular}

probability of the most beaten individual becoming the dominant is less than the probability of this position being occupied by one of the remaining less bitten individuals. The greater frequency of the most beaten individuals becoming dominants in relation to the probability of this taking place indicates that there is a tendency for the most beaten male to take over the dominant's place (Table 2).

The populations in series III and IV were formed by combined two separate "original " populations in which social organization had been 
observed for 1 week. Analysis of the social organization of the remaining populations makes it possible to give an answer to the question as to whether, as dominants are successively removed, their place is occupied by individuals from the same "original " population as the dominant, or whether this is a purely fortuitous phenomenon (Table 3). Out of a total of 26 combined populations in 18 of them two, and in 11 as many as three, successive dominants originated from the same "original " population. In order to find out whether this is accidental calculation was made of the possibility that for 3 successive weeks dominants would be males from the same population. The empirical value $(P=0.37)$ formed evidence of the existing tendency for the dominant's position to be occupied by individuals belonging to the same population as the first dominant.

A check was made to see which individual in the hierarchy of "original " populations occupies the dominant's place when two populations are combined. After removing the partitions from the cages it proved that in 23 of the newly-formed populations, out of a total number of 26 analysed, mice which had been dominants in one of the populations before they were combined became dominants, and in 3 cases other males.

\section{DISCUSSION}

The observed decrease in the number of fights during the existence of the population (Figs 1,2) agrees with the data given by $\mathrm{Petruse-}$ wicz (1966) and can be explained by the process of setting in order relations between individuals (Andrzejewski, Petrusewicz \& $\mathrm{W}$ a l k ow a, 1963). The increased number of fights after the dominant has been removed may be due to disturbances in the social organization hitherto prevailing. This increase, however, occurs not only after the dominant is removed, but also after taking away another individual or adding several new individuals to the population, as the result of which operation the existing social organization of the population is disturbed (P etrusewicz, 1963).

A ndrzejewski et al. (1963) interpreted the increase in the number of fights after introduction of a new mouse as a manifestation of disturbance to the existing social organization. The increased number of fights' observed after introducing the first dominant can be interpreted similarly.

The authors referred to above showed that when new individuals are introduced into a population it is not only the dominant which fights with them, but the whole population. The tendency for one population to dominate over the other when the two are combined, which has been 
observed in this study, may be analogical to the above observations. In this case the whole population defends its position against the other population. It would seem that the defeated dominant of one population automatically subordinates this population to the other, which is represented by the winner. The conclusion can be reached from this that after the dominant is removed the situation does not change but persists until males from the dominating population are removed from the cage. The populations would thus appear to "remember " that one of them is subordinated, and the other dominates.

The fact that the most beaten males occupy the dominant's position can be explained by their probably being more active mice and perhaps sometimes even provoke the dominant to fight. It is thus not difficult to understand that they are the mice most beaten by the dominant, and also that during the many fights in which they engage they acquire experience and after the dominant's removal take over its position. This would agree with the suggestion made by Calhoun (1956) who, wanting to find the activity coefficient of mice on the basis of their fights, took into consideration not only the fights won but also those lost. $\mathrm{He}$ considered that it is not only the fact of the male having won the fight is important, but also that when fighting it demonstrated its activity (even though it lost the fight).

The time required to set the social organization in order is short, but is prolonged when successive dominants are removed. This can be explained by the decreased individual tendency to occupy the position of dominant or by the simplification of relations between individuals as the number of males decreases.

Introduction into the population of the first dominant caused its return to its former place in $37 \%$ of the cases and this took place within 5 days time. W a lk ow a (1964) found that after a new individual had been introduced into the population the time required for its possible occupation of dominant's position is longer than one month. The introduced individual occupies the lowest rung in the social hierarchy and at least as long a time is required for it to reach the position of dominant. It would therefore appear that return to the position of dominant is conditioned either by the individual characters of the mouse removed from the population, which predominate over the population situation and enable the mouse to re-occupy its former position of dominant, or else the population still remembers it.

Acknowledgements: I am indebted to Dr. W. Walkow a for the advice and guidance freely given during the preparation of this study, to Dr. hab. R. A n d r z ejewski for consulation and assistance in preparing this paper, and J. G10gow s ka, M. Sc. for her help in statistical elaboration of results. 


\section{REFERENCES}

1. Andrzejewski R., Petrusewicz K. \& Walkowa W., 1963: Absorption of newcomers by a population of white mice. Ekol. pol. A, 11, 7: 223-240.

2. Brown R. Z., 1953: Social behaviour, reproduction and population changes in the house mouse. Ecol. Monogr., 23, 3: 217-240.

3. Calhoun J. B., 1956: A comparative study of the social behaviour of two strains of house mouse. Ecol. Monogr., 26, 1: 81-103.

4. Crowcroft P., 1962: Relating the laboratory environment to nature. Laboratory Animals Centre Collected Papers 11.

5. Petrusewicz K., 1963: Population growth induced by disturbance in the ecological structure of the population. Ekol. pol. A, 11, 3: 87-125.

6. Petrusewicz K., 1966: Dynamics, organization and ecological structure of population. Ekol. pol. A, 14, 25: 413-436.

7. Petrusewicz K. \& Andrychowska R., 1960: Dalsze badania nad wplywem populacji na rezultat walk samców myszy. Ekol. pol. A, 8, 15: 325-333.

8. Petrusewicz K. \& Wilska T., 1959: Investigation of the influence of interpopulation relations on the result of fights between male mice. Ekol. pol. A, 7, 14: 357-390.

9. Southwick Ch., 1955: Regulatory mechanisms of house mouse populations: social behaviour affecting survival. Ecology, 36: 627-634.

10. Uhrich J., 1938: The social hierarchy in albino mice. J. comp. Psychol., 25: $373-413$.

11. Walkowa W., 1964: Rate of absorption of newcomers by a confined white mouse population. Ekol. pol. A, 12, 18: 325-335.

Accepted, December 22, 1971.

Institute of Ecology,

Polish Academy of Sciences,

Warszawa, Nowy Swiat 72 .

Zenona NOWAK

WPEYW USUWANIA DOMINANTA NA ORGANIZACJE DOMINACYJNA

W POPULACJI MYSZY LABORATORYJNEJ

Streszczenie

Praca miała na celu stwierdzenie jak zmienia się organizacja dominacyjna w populacjach bialych myszy po usunięciu z nich dominanta. Badania przeprowadzono w 4 seriach na 66 populacjach myszy laboratoryjnej. Myszy w wieku 3-5 miesięcy umieszczono w klatkach o wymiarach $160 \times 40 \times 15 \mathrm{~cm}$. Obserwowano agresywne kontakty między osobnikami populacji i określano dominanta na podstawie maksymalnej liczby wygranych walk. W seriach I i II obserwowano populacje zlożone z 5 samców i 5 samic. Po tygodniu obserwacji z populacji usunięto dominanta a następnie co tydzień dwa kolejne dominanty, czyli $\mathrm{z}$ każdej populacji po 3 
samce. Po 4 tygodniach do populacji wpuszczono $\mathrm{z}$ powrotem pierwszego dominanta. W seriach III i IV obserwowano populacje złożone z 3 samców i 3 samic w klatkach przegrodzonych na 2 części. Po tygodniu obserwacji czyli po ustaleniu dominanta dla każdej populacji wyjęto przegródki dzielące klatki. Przez następny tydzień obserwowano dominanta wspólnego dla obu populacji i usunięto jego a po dalszych tygodniowych obserwacjach jeszcze dwa kolejne dominanty.

Przeanalizowano intensywność gryzień w czasie trwania eksperymentu (Ryc. 1, 2) i stwierdzono, że we wszystkich seriach następuje spadek liczby walk w miarę uplywu czasu i ponowny wzrost po wpuszczeniu do populacji pierwszego dominanta. Obserwuje się także spadek liczby walk przypadających na jednego samca w kolejnych tygodniach eksperymentu (Ryc. 3). Wskazuje to, że ogólny spadek liczby walk nie jest wynikiem zmniejszonej liczby samców pod wpływem usuwania dominantów. Porównano także nasilenie walk w czasie kolejnych obserwacji po każdym wyjęciu dominanta (Ryc. 4).

Stwierdzono, że zawsze po założeniu populacji jak i po usunięciu dwóch pierwszych dominantów organizacja dominacyjna powstaje ponownie (Tabela 1). Pierwszy dominant po ponownym wpuszczeniu do populacji tylko w $37 \%$ przypadków powraca na dawne miejsce.

Przeánalizowano jaki okres czasu jest potrzebny aby po usunięciu dominanta następny osobnik zajął jego pozycję (Ryc. 5). Wartości określające ten okres wahają się od 1,7 do 3,3 dnia.

Stwierdzono, że istnieje tendencja do zajmowania pozycji dominanta przez najbardziej bitego osobnika (Tabela 2).

Połączenie dwóch populacji dało możliwość zbadania czy przy kolejnych usunięciach dominantów ich miejsce zajmują osobniki z tej samej »pierwotnej« populacji. Stwierdzono, że istnieje tendencja do zajmowania pozycji dominanta przez osobniki z tej samej populacji co świadczy o dominacji jednej populacji nad drugą. 